\title{
O NEGÓCIO PROCESSUAL SANEADOR: ENTRE O PRINCÍPIO DISPOSITIVO MATERIAL E O IURA NOVIT CURIA
}

\section{THE CURATIVE PROCEDURAL CONVENTION: BETWEEN THE DISPOSITIVE PRINCIPLE IN THE MATERIAL SENSE AND THE IURA NOVIT CURIA}

\author{
EL NEGOCIO PROCESAL SANEADOR: ENTRE EL PRINCIPIO DISPOSITIVO \\ MATERIAL Y EL IURA NOVIT CURIA
}

\author{
EDUARDO KOCHENBORGER SCARPARO \\ https://orcid.org/0000-0001-7535-5111 / http://lattes.cnpq.br/4472388798257051 / eduardo@scarparo.adv.br \\ Universidade Federal do Rio Grande do Sul \\ Porto Alegre, Rio Grande do Sul, Brasil.
}

\author{
CAROLINe Pomjé \\ http://orcid.org/0000-0001-8726-6474 / http://lattes.cnpq.br/6826629981011106 / carol.pomje@hotmail.com \\ Universidade Federal do Rio Grande do Sul. \\ Porto Alegre, Rio Grande do Sul, Brasil.
}

\begin{abstract}
RESUMO
O presente estudo analisa o âmbito de incidência do negócio jurídico processual constante no art. 357 , $\$ 2^{\circ}$, do CPC/2015, que prevê a possibilidade de realização de saneamento consensual do processo, ensejando a delimitação do objeto litigioso por meio do consenso entre os litigantes. Partindo-se do estudo do princípio dispositivo em sentido material e da divisão de tarefas entre juiz e partes, busca-se verificar a redução da incidência do adágio iura novit curia sobre a determinação da fundamentação jurídica da causa de pedir em decorrência, justamente, da convenção processual acima mencionada.
\end{abstract}

Palavras-chave: Convenção; lura novit curia. Processo civil. Saneamento processual.

\begin{abstract}
The present study intends to analyze which is the ambit of incidence of procedural convention constant in art. 357 , $\$ 2^{\circ}$, of Code of Civil Procedure, which provides the possibility of consensual procedural curative acts, allowing the delimitation of the litigious object by the litigants. Starting by the study of dispositive principle in the material sense and the labor division between the judge and the parts, intends to check the reduction in incidence of iura novit curia adage on the determination of the juridical basis of causa petendi because of, precisely, the procedural convention constant in art. $357, \$ 2^{\circ}$, of Code of Civil Procedure.
\end{abstract}

Keywords: Civil procedure; Convention; lura novit curia; Procedural curative acts.

\section{RESUMEN}

El presente estudio analiza el ámbito de incidencia del negocio jurídico procesal constante en el art. De acuerdo con lo establecido en la Ley Orgánica del Poder Legislativo, en el marco de la Convención de las Naciones Unidas. A partir del estudio del principio dispositivo en sentido material y de la división de tareas entre juez y partes, se busca verificar la reducción de la incidencia del adagio iura novit curia sobre la determinación de la fundamentación jurídica de la causa de pedir, en consecuencia, justamente, convención de procedimiento antes mencionada.

Palabras clave: Convención; lura novit curia. Proceso civil. Saneamiento procesal. 


\section{SUMÁRIO}

INTRODUÇÃO; 1 DO OBJETO LITIGIOSO E SUA RELAÇÃO COM O PRINCÍPIO DISPOSITIVO MATERIAL; 2 CAUSA DE PEDIR E IURA NOVIT CURIA NO PROCESSO CIVIL BRASILEIRO; 2.1 Causa de pedir; 2.2 Delimitações de incidência do iura novit curia; 3 AS CONVENÇÕES PROCESSUAIS E AS LIMITAÇÕES AOS PODERES DO JUIZ; 3.1 Processo e privatismo; 3.2 Art. 357, $\$ 2^{\circ}$, do CPC/2015: a delimitação do objeto litigioso via convenção processual; CONCLUSÃO; REFERÊNCIAS.

\section{INTRODUÇÃO}

O direito processual civil brasileiro erigiu-se considerando ser o processo uma atividade de interesse público e que, por isso, inadmitia ingerências significativas dos particulares sobre sua conformação. Exemplo disso é que elementos tradicionalmente relacionados com a expressão da autonomia privada foram reduzidos ou até mesmo excluídos pela doutrina em geral ${ }^{1}$. A exclusão desses institutos do estudo processual é fruto do contexto histórico-científico vivido a partir de Bülow ${ }^{2}$ para a criação de uma nova disciplina autônoma e independente do direito material ${ }^{3}$. Certo é que, hoje, aquela separação entre processo e direito material sofreu irreversíveis desgastes; mas algumas consequências da incorporação originária desse ideário permanecem silentes, e são irrefletidamente repetidas na doutrina em geral. Nessa esteira estão os intensos poderes do juiz presentes na praxe jurídica brasileira, de modo que o publicismo processual durante muito tempo ocupou um papel de destaque, com a vedação, como regra, à alteração procedimental realizada pelas partes litigantes.

As modificações introduzidas pelo advento do CPC/2015 ensejaram uma mudança paradigmática, mormente considerando a proteção da autonomia da vontade das partes para promover alterações em aspectos processuais. A cláusula geral de atipicidade dos negócios jurídicos processuais, prevista no art. 190, do CPC/2015, assumiu coro para os fins de dar eficácia à vontade privada sobre o agir processual $^{4}$, com a possibilidade de adaptação do procedimento pelas partes:

\footnotetext{
${ }^{1}$ Por todos, em relevante livro de Calmon de Passos: "A vontade e a causa, normalmente, são irrelevantes em matéria de atos processuais". PASSOS, José Joaquim Calmon de. Esboço de uma teoria das nulidades aplicadas às nulidades processuais. Rio de Janeiro: Forense, 2005, p. 58.

2 BÜLOW, Oskar. La teoría de las excepciones procesales y los presupuestos procesales. Tradução de Miguel Angel Rosas Lichtschein. Buenos Aires: EJEA, 1964.

${ }^{3}$ Antônio do Passo Cabral indica que a concentração do fenômeno processual na concepção de forma é fruto de "uma espécie de xenofobismo" dos processualistas em quererem apartar o processo do direito material. CABRAL, Antônio do Passo. Nulidades no processo moderno. Rio de Janeiro: Forense, 2009, p. 160.

4 A respeito da ingerência da vontade nos atos processuais: SCARPARO, Eduardo. As invalidades processuais civis na perspectiva do formalismo-valorativo. 1. ed. Porto Alegre: Livraria do Advogado,
} 
[...] as convenções processuais não significam um retorno impensado ao privatismo romano, ou uma guinada ao formato anglo-americano do processo adversarial, mas um tratamento mais balanceado da tensão entre publicismo e privatismo, com a redução (não eliminação!) dos poderes do juiz em razão da atuação legítima das partes. ${ }^{5}$

Com efeito, a possibilidade de alteração do procedimento pelas partes influencia também os poderes atribuídos ao juiz, dentre eles a incidência da dicção iura novit curia, de acordo com a qual ao julgador caberia o conhecimento acerca do direito aplicável ao caso concreto, enquanto que a exposição dos fatos em juízo seria atribuição do demandante e do demandado (no mesmo sentido do brocardo narra mihi factum, narro tibi ius). Nesse particular, propõe-se estabelecer em que medida o negócio jurídico saneador interfere no objeto litigioso e, em especial, nos poderes do juiz de aplicar livremente fundamentos jurídicos não deduzidos pelas partes.

\section{DO OBJETO LITIGIOSO E SUA RELAÇÃO COM O PRINCÍPIO DISPOSITIVO}

\section{MATERIAL}

A iniciativa da demanda compete às partes, consistindo em um direito subjetivo, de modo que "ao titular do direito caberá decidir livremente se o exercerá ou deixará de exercêlo"6. É a parte quem determina o alcance da atividade jurisdicional, indicando quando a atuação do Poder Judiciário será necessária e sobre qual situação litigiosa aquela deverá incidir ${ }^{7}$. Tal delimitação do objeto litigioso pela parte autora relaciona-se diretamente com o princípio dispositivo.

O princípio dispositivo em sentido material (ou próprio) indica competir à parte a iniciativa da causa e a delimitação de seu objeto (Dispositionsmaxime), relacionando-se com a demanda, portanto. Em sentido formal (ou impróprio) diz respeito ao desenvolvimento interno

2011, p. 54-60. Igualmente, impõe-se a consulta em SILVA, Paula Costa. Acto e Processo: o dogma da irrelevância da vontade na interpretação e nos vícios do acto postulativo. Coimbra: Coimbra Editora, 2003.

${ }^{5}$ CABRAL, Antonio do Passo. Convenções processuais. Salvador: Editora JusPodivm, 2016, p. 137.

${ }^{6}$ SILVA, Ovídio Araújo Baptista da. Curso de Processo Civil: processo de conhecimento, volume 1. 6. ed. rev. e atual. com as Leis 10.352, 10.358/2001 e 10.444/2002. São Paulo: Editora Revista dos Tribunais, 2002, p. 64.

7 ARENHART, Sergio Cruz. Reflexões sobre o princípio da demanda. In: FUX, Luiz; NERY JR., Nelson; WAMBIER, Teresa Arruda Alvim (coord.). Processo e Constituição: estudos em homenagem ao Professor José Carlos Barbosa Moreira. São Paulo: Editora Revista dos Tribunais, 2006, p. 587-603, p. 590. 
do processo (Verhandlungsmaxime) ${ }^{8}$, alcançando as projeções sobre o procedimento, faculdades e poderes das partes e do juiz. Essa bipartição do princípio, reforçada por Cappelletti ${ }^{9}$ a partir de Carnacini $^{10}$, conduz a um indispensável enfrentamento para distribuição dos poderes das partes e do juiz no processo civil.

Em sentido material, o princípio dispositivo está ligado à relação de direito material ${ }^{11}$, uma vez que indica competir exclusivamente à parte a iniciativa, a delimitação da causa de pedir e dos pedidos, limitando-se o objeto da cognição pelo juízo ${ }^{12}$. Por conta dele, a parte tem total controle sobre a propositura da demanda, pois é a pretensão material que deve ser

8 Leciona Bedaque que a distinção operada na doutrina tedesca entre o princípio dispositivo reflete diferentes fenômenos relativos aos poderes do juiz. BEDAQUE, José Roberto dos Santos. Poderes Instrutórios do Juiz. 4. ed. São Paulo: Revista dos Tribunais, 2009, p. 87-97. Vale ressaltar, transcrevendo Barbosa Moreira, a respeito da terminologia da doutrina alemã: "para designar a diretriz que subordinava a atividade do juiz à iniciativa da parte, cunhou-se o termo Verhandlungsmaxime, que ao pé da letra significa "máxima (ou princípio) do debate", e estaria possivelmente a indicar a limitação do material utilizável no julgamento àquilo que os litigantes mesmo cuidem de trazer à discussão em juízo. Não surpreende que se tenha considerado inexpressiva a denominação, e imprópria como veículo da idéia que se pretendia sugerir; nem que, algumas décadas mais tarde, se propusesse outra, Dispositionsmaxime, em que era evidente a sugestão. Todavia, o nome primitivo não foi abandonado. Em vez disso, ganhou terreno, pouco a pouco, na doutrina, a tendência a distinguir duas classes de problemas: uma relacionada com a liberdade do titular do direito de utilizar ou não o instrumento do processo para a respectiva vindicação, outra como modo de funcionar o mecanismo processual no tocante aos fatos e à prova deteste. Muitos autores passaram a reservar para o âmbito do segundo grupo de fenômenos o emprego do binômio Verhandlungsmaxime - Untersuchungsmaxime e a usar de preferência, com relação ao primeiro grupo, as expressões Dispositionsmaxime e Offizialmaxime". MOREIRA, José Carlos Barbosa. 0 problema da "divisão do trabalho" entre juiz e partes: aspectos terminológicos. Revista de Processo, São Paulo, n. 41. p. 7-14, jan/mar.1986, p. 9. Em reforço à terminologia e a distinção na doutrina alemã: MATTOS, Sérgio Luiz Wetzel de. Da iniciativa probatória do juiz no processo civil. Rio de Janeiro: Forense, 2001, p. 30-33.

${ }_{9}^{9}$ CAPPELLETTI, Mauro. La testimonianza della parte nel sistema dell'oralità. v. 1. Milão: Giuffrè, 1962, p. 303-365.

${ }^{10}$ CARNACINI, Tito. Tutela giurisdizionale e tecnica del processo. In: Studi in onore di Enrico Redenti. v. 2. Milão: Giuffrè, 1951, p. 693-772.

11 MOREIRA, José Carlos Barbosa. O problema da "divisão do trabalho" entre juiz e partes: aspectos terminológicos. Revista de Processo, São Paulo, n. 41, p. 7-14, jan/mar.1986, p. 11. Nesse sentido, também, é a lição de Carnacini: "O Dispositionsprinzip em sentido estrito (em antítese ao Verhandlungsprinzip) não é outra coisa senão relativo ao direito subjetivo ainda quando se recorre à tutela jurisdicional e com isso ao instrumento processo civil". CARNACINI, Tito. Tutela giurisdizionale e tecnica del processo. In: Studi in onore di Enrico Redenti. v. 2. Milão: Giuffrè, 1951, p. 752. Igualmente, tratando dos princípios fundamentais do processo civil no direito comparado: " $O$ primeiro $e$ mais importante desses princípios é o que deriva da natureza mesma do direito substancial do qual, mediante $o$ processo se pede a proteção. Se fala, a esse propósito, pela doutrina européia, de um princípio dispositivo (Dispositionsprinzip ou Dispositionsmaxime): o princípio ou a máxima de a disposição de parte". CAPPELLETTI, Mauro. El proceso civil en el derecho comparado: las grandes tendências evolutivas. Tradução de Santiago Sentís Melendo. Buenos Aires: EJEA, 1973, p. 17.

12 Cappelletti propõe: “chamar de princípio (e processo) dispositivo em sentido material ou em sentido próprio aquele, com que se indica a existência de um poder exclusivo das partes no postular a tutela jurisdicional e no fixar o objeto do juízo" CAPPELLETTI, Mauro. La testimonianza della parte nel sistema dell'oralità. v. 1. Milão: Giuffrè, 1962, p. 357. 
afirmada e sustentada, por ato de livre vontade do autor em exigir em juízo as eficácias do direito subjetivo que alega ter. Da faceta material do princípio dispositivo é que decorre a restrição ao juiz à pretensão material afirmada pelo autor e a restrição da atuação jurisdicional aos fatos narrados pelas partes. De igual maneira, por conta dela é impedido o juiz de se opor a atos de disponibilidade do direito material praticados pelas partes no bojo do processo, como a renúncia, o reconhecimento do pedido ou a transação ${ }^{13}$.

Concerne, assim, ao poder de decidir sobre a instauração do processo, sobre a respectiva subsistência e sobre a delimitação do litígio ${ }^{14}$. Carnacini, em texto seminal a respeito, expõe que se deve reconhecer a existência de um princípio fundamental de dependência da vontade do interessado para a instauração do processo. As normas relacionadas à essa iniciativa, contudo, não dizem respeito ao modo de ser do instrumento, mas à proteção jurídica dada aos interesses materiais pelo exercício da ação ${ }^{15}$, razão pela qual assevera tratar-se da busca pela parte de escopos ultraprocessuais ${ }^{16}$. Assim, exige-se a provocação da parte para conhecimento da exceção material (exceptiones iuris); a proibição de se conceder tutela aquém, além ou

13 Cappelletti aduz que as principais manifestações do princípio dispositivo no direito comparado em sentido material respeitam (a) a vedação do juiz de instaurar ex officio um processo; (b) vedar o juiz de "contrademandar" de ofício, opondo exceções do demandado; (c) vedar o juiz de decidir além dos limites da demanda; (d) a de que apenas as partes e eventuais terceiros interessados podem impugnar uma decisão tomada; (e) o poder das partes de pôr fim ao processo mediante uma transação. CAPPELLETTI, Mauro. El proceso civil en el derecho comparado: las grandes tendencias evolutivas. Tradução de Santiago Sentís Melendo. Buenos Aires: EJEA, 1973, p. 23-36.

14 MOREIRA, José Carlos Barbosa. O problema da "divisão do trabalho" entre juiz e partes: aspectos terminológicos. Revista de Processo, São Paulo, n. 41, p. 7-14, jan/mar.1986, p. 10.

${ }^{15}$ CARNACINI, Tito. Tutela giurisdizionale e tecnica del processo. In: Studi in onore di Enrico Redenti. v. 2. Milão: Giuffrè, 1951, p. 744. Não se acolhe, contudo, na posição de Carnacini, que o exercício da ação não se confunde com o exercício do direito material, dado o estado atual do problema relativo à ação. Sobre a polêmica da ação, ver MACHADO, Fábio Cardoso; AMARAL, Guilherme Rizzo (orgs.). Polêmica sobre a ação. Porto Alegre: Livraria do Advogado, 2006. A respeito, convém também consultar: ALVARO DE OLIVEIRA, Carlos Alberto. Teoria e prática da tutela jurisdicional. Rio de Janeiro: Forense, 2008. Também criticando essa posição, Cappelletti argumenta: "Parece certo, na verdade, que um ato jurídico somente pode dizer-se material ou processual, enquanto representa o exercício de um poder e em geral o desenvolvimento de uma situação jurídica, respectivamente, de direito material ou de direito processual. (...) Somente quem sustente ser a ação um direito material pode subtrair da esfera dos atos processuais o ato da demanda". (p. 315). Daí, complementa "não é verdadeiro que o princípio dispositivo cesse de ser um princípio processual, e possa, portanto, simplesmente derivá-lo, ou adicionalmente identificá-lo ou confundi-lo com a disponibilidade do direito substancial, e portanto, com a natureza privada deste" (p. 317). CAPPELLETTI, Mauro. La testimonianza della parte nel sistema dell'oralità. v. 1. Milão: Giuffrè, 1962, p. 315-317.

${ }^{16}$ CARNACINI, Tito. Tutela giurisdizionale e tecnica del processo. In: Studi in onore di Enrico Redenti. v. 2. Milão: Giuffrè, 1951, p. 700. 
diversa da postulada pela parte (ne eat iudex ultra petita partium); a impugnabilidade da sentença apenas pelas partes; e o princípio da disponibilidade privada do processo ${ }^{17}$.

A apresentação do objeto litigioso tem relação, portanto, com as projeções de vontade da parte autora, sob o alcance do princípio dispositivo em sentido material. Nesse passo é salutar indicar que o conceito de objeto litigioso do processo apresenta-se mais estreito que o de objeto do processo: enquanto que o segundo conceito abarca tudo aquilo que é determinante para a intelecção judicial, apenas o mérito diz respeito ao primeiro ${ }^{18}$. 0 objeto litigioso é formado, portanto, pelo pedido e pela causa de pedir (causa petendi), refletindo aquilo que as partes trouxeram ao processo para apreciação e julgamento ${ }^{19}$.

\section{CAUSA DE PEDIR E IURA NOVIT CURIA NO PROCESSO CIVIL BRASILEIRO}

\subsection{Causa de pedir}

$\mathrm{Na}$ delimitação do objeto litigioso tem papel fundamental a noção de causa de pedir, que representa um dos institutos teoricamente mais controvertidos do direito processual civil. A fim de facilitar sua conceituação e, também, a sua delimitação, desenvolveram-se ao longo dos séculos, com fulcro na investigação acerca do conteúdo do objeto litigioso, duas teorias que buscaram identificar os elementos que acabam por constituí-la: a teoria da substanciação e a teoria da individualização $20-21$.

\footnotetext{
${ }_{17}$ ALVARO DE OLIVEIRA, Carlos Alberto. Do formalismo no processo civil. 4. ed. São Paulo: Saraiva, 2010, p. 197-198.

${ }_{18}$ SANCHES, Sydney. Objeto do processo e objeto litigioso do processo. Revista da AJURIS. Ano VI - 1979, julho. p. 133-156, p. 151-156.

${ }_{19}$ CABRAL, Antonio do Passo. Convenções processuais. Salvador: Editora JusPodivm, 2016, p. 89.

20 TUCCI, José Rogério Cruz e. A denominada "situação substancial" como objeto do processo na obra de Fazzalari. Revista de Processo, v. 68/1992, p. 271-281, out-dez, 1992, p. 272.

21 Acerca de tal diferenciação merecem destaque as considerações de Otávio Augusto Dal Molin Domit: "[...] de um lado, houve os que defendiam que a demanda deveria especificar o direito para o qual se requeria tutela. De outro, houve os que opinavam que a demanda deveria indicar todos os fatos relevantes para um julgamento de procedência. Logo, na ação fundada em domínio, os adeptos da primeira corrente diziam bastar a indicação do domínio como fundamento da demanda, ostentando-se irrelevante a causa aquisitiva (compra e venda ou testamento, por exemplo). Porém, os adeptos da segunda corrente pregavam que a passagem de um a outro título de aquisição importaria necessariamente modificação da demanda. A essas duas posições deram-se os nomes, respectivamente, de teoria da individualização e de teoria da substanciação, fazendo surgir a polêmica que posteriormente foi exportada para além dos domínios do direito alemão, adquirindo ampla notoriedade”. In DOMIT, Otávio Augusto Dal Molin. A causa de pedir no Novo Código de Processo Civil: necessidade de superação do mito da substanciação em prol de
} 
Resumidamente, para a teoria da substanciação (Substantiierungstheorie), a causa de pedir consiste no "fato ou complexo de fatos aptos a suportarem a pretensão do autor", de modo que prevaleceriam os fatos sobre a relação jurídica ${ }^{22}$. Convém destacar que, no âmbito de tal teorização, a coisa julgada abrangeria a decisão considerados tão somente os fatos constitutivos do direito do autor indicados ao longo da demanda, de modo que "outros fatos não alegados pelo autor poderão ser introduzidos por ele em demanda diversa, até mesmo com pedido idêntico" 23 , uma vez que "a alteração do quadro fático do qual decorre a consequência perseguida pelo autor, conceituado desta forma como situação elementar da causa de pedir, importa na mudança de ação"24.

A teoria da individualização (Individualisierungstheorie) deposita importância na indicação da relação jurídica constitutiva do direito, enquanto fundamento jurídico, de modo que a indicação do fato constitutivo do direito afirmado em juízo mostrar-se-ia desnecessária ${ }^{25}$ dessa forma, a alteração dos fatos constitutivos, no curso do processo, não ensejaria alteração da demanda ${ }^{26}$, pois considerada a relação jurídica controvertida como aspecto central e determinante para identificação da causa de pedir ${ }^{27}$.

A similitude prática existente entre essas teorias acerca da compreensão da causa de pedir foi destacada por Elio Fazzalari ${ }^{28}$, o qual asseverava que "escolher entre 'a alegação dos

uma nova compreensão da demanda no processo civil brasileiro. Novo CPC doutrina selecionada, v. 2: procedimento comum. Coordenador geral: Fredie Didier Jr.; Organizadores Lucas Buril de Macêdo, Ravi Peixoto, Alexandre Freire, p. 31-64. Salvador: Editora Juspodivm, 2016, p. 37.

22 PINTO, Junior Alexandre Moreira. A causa petendi e o contraditório. São Paulo: Editora Revista dos Tribunais, 2007, p. 35.

${ }^{23}$ PINTO, Junior Alexandre Moreira. A causa petendi e o contraditório. São Paulo: Editora Revista dos Tribunais, 2007, p. 37.

${ }^{24}$ HOFFMANN JÚNIOR, Lírio. A teoria da substanciação e seus reflexos sobre a coisa julgada. In: OLIVEIRA, Pedro Miranda de; LUCON, Paulo Henrique dos Santos (coord.). Panorama atual do novo CPC. Florianópolis: Empório do Direito, 2016. p. 251-270, p. 267.

${ }_{25}$ PINTO, Junior Alexandre Moreira. A causa petendi e o contraditório. São Paulo: Editora Revista dos Tribunais, 2007, p. 43.

${ }^{26}$ MESQUITA, José Ignácio Botelho de. A coisa julgada. Rio de Janeiro: Forense, 2006, p. 48.

27 Anota-se que parte da processualística alemã, com fulcro na teoria da individualização, "tende a extirpar do objeto do processo a causa de pedir, ensejando verdadeira cisão entre direito substancial e processo". TUCCl, José Rogério Cruz e. A denominada "situação substancial" como objeto do processo na obra de Fazzalari. Revista de Processo. vol. 68/1992, p. 271-281, out-dez, 1992, p. 03.

${ }^{28}$ No original, lê-se: "Mi pare, peraltro, che le contrapposte soluzioni siano poco o punto distanti e che, anzi, si possano giustapporre come due facce della stessa realtà: propugnare, infatti, l'allegazione dei fatti costitutivi o quella del rapporto giuridico significa porsi, rispettivamente, dal punto di vista della fattispecie (sostanziale) e da quelo degli effetti che ne promanano, cioè da dua punti di vists perfettamente compatibili, anzi corrispondenti. Con la sola avvertenza, del resto pacificamente ritenuta, che il nomen iuris che l'attore sia per assegnare alla situazione giuridica sostanziale addotta non è vincolante per il giudice". In FAZZALARI, Elio. Note in Tema di Diritto e Processo. Milano: Dott. A. Giuffrè Editore, 1957, p. 118-119. 
fatos constitutivos' [substanciação] ou 'a afirmação da relação jurídica' [individualização], significa pôr-se, respectivamente, do ponto de vista da fattispecie (substancial) e daquele dos efeitos que dela derivam"29, sendo que, para referido processualista, o ingresso do direito subjetivo no processo dar-se-ia por intermédio da alegação da causa de pedir ${ }^{30}$. 0 autor, embora tenha frisado a relevância das alegações fáticas e jurídicas para a determinação da causa de pedir, ressaltou que o nomen juris atribuído pelo demandante à situação jurídica substancial deduzida não vincularia o Magistrado ${ }^{31}$, sendo que a denominação escolhida pelo demandante, de acordo com a opinião geral da doutrina, sequer comporia a causa de pedir ${ }^{32}$.

Em qualquer que seja a teoria acolhida para identificação da causa de pedir, tem igualmente papel predominante na sua compreensão as noções atinentes à fundamentação jurídica. Inicialmente, essa não pode ser confundida com a fundamentação legal (nomen juris ou a indicação do texto de lei pelo autor). Tal distinção é extremamente relevante para consideração da incidência jurídica atual do brocardo iura novit curia.

Boa parte da doutrina equivoca-se ao confundir qualificação legal com qualificação jurídica. Enquanto a primeira traduz a mera indicação do dispositivo legal invocado pela parte, a segunda representa a denominada causa de pedir próxima, traduzida como o enquadramento dos fatos no ordenamento jurídico, isto é, a subsunção daqueles fatos constitutivos (causa remota) à violação ocorrida no plano material ${ }^{33}$.

A fundamentação jurídica, exigida pelo art. 319, inciso III, do Código de Processo Civil/2015, como requisito da petição inicial, consiste em um enquadramento dos fatos a determinada moldura jurídica, "correspondendo, em síntese, à demonstração da repercussão jurídica que os fatos (jurídicos) têm para que se considere fundada a pretensão delineada pelo autor”34. Por outro lado, a fundamentação legal representa, unicamente, qualificação legal dos

29 TUCCI, José Rogério Cruz e. A denominada "situação substancial" como objeto do processo na obra de Fazzalari. Revista de Processo, v. 68/1992, p. 271-281, out-dez, 1992, p. 04.

30 DOMIT, Otávio Augusto Dal Molin. lura novit curia e causa de pedir: o juiz e a qualificação jurídica dos fatos no processo civil brasileiro. In: MARINONI, Luiz Guilherme; ARENHART, Sérgio Cruz; MITIDIERO, Daniel (coord.). Coleção o novo processo civil. São Paulo: Editora Revista dos Tribunais, 2016, p. 165.

31 DOMIT, Otávio Augusto Dal Molin. lura novit curia e causa de pedir: o juiz e a qualificação jurídica dos fatos no processo civil brasileiro. In: MARINONI, Luiz Guilherme; ARENHART, Sérgio Cruz; MITIDIERO, Daniel (coord.). Coleção o novo processo civil. São Paulo: Editora Revista dos Tribunais, 2016, p. 165.

32 Vide PINTO, Junior Alexandre Moreira. A causa petendi e o contraditório. São Paulo: Editora Revista dos Tribunais, 2007, p. 20.

33 PINTO, Junior Alexandre Moreira. A causa petendi e o contraditório. São Paulo: Editora Revista dos Tribunais, 2007, p. 82.

${ }^{34}$ DOMIT, Otávio Augusto Dal Molin. lura novit curia e causa de pedir: o juiz e a qualificação jurídica dos fatos no processo civil brasileiro. Coleção o novo processo civil. Coordenadores: Luiz Guilherme Marinoni, Sérgio Cruz Arenhart, Daniel Mitidiero. São Paulo: Editora Revista dos Tribunais, 2016, p. 272. 
fatos trazidos à lume pelo demandante, de maneira que o artigo da lei eventualmente invocado na exordial não comporia a causa petendi $i^{35-36}$.

Exemplificativamente, se a parte autora propõe demanda justificando haver responsabilidade civil objetiva, poderá fazer uso de uma gama de disposições da lei para esse fim. Se valeu-se do parágrafo único do art. 927, do $C C B / 2002$, nada impediria que o juiz considerasse a questão a partir do disposto no art. 14, do Código de Defesa do Consumidor, se for o caso amparado em uma relação consumerista.

Contudo, não poderia o juiz apreciar a relação jurídica entre as partes a partir da noção de enriquecimento sem causa, pois assim procedendo, estaria alterando o fundamento jurídico, transformando o objeto litigioso e instaurando ex officio uma pretensão não exercida pelo autor. 0 resultado seria a violação dos limitadores de inércia da jurisdição fundados no princípio dispositivo em sentido material que impõe a exclusividade ao autor para que, por sua vontade, alegue uma pretensão material vinculada a um direito subjetivo que sustente possuir.

No campo de aplicação do adágio iura novit curia, considerando-se o entendimento doutrinário pacífico, está a possibilidade de alteração da fundamentação legal da demanda pelo juiz. A abrangência do brocardo para alteração do fundamento jurídico, contudo, é tema de larguíssima controvérsia e merece aprofundamento por conta das relações entre princípio dispositivo e causa de pedir.

\subsection{Delimitações de incidência do iura novit curia}

0 adágio iura novit curia, cuja aplicação é secular, teve evolução lenta e extensa ${ }^{37}$ : foi na fase da extraordinaria cognitio romana (período em que o processo romano adquiriu um viés

\footnotetext{
35 PINTO, Junior Alexandre Moreira. A causa petendi e o contraditório. São Paulo: Editora Revista dos Tribunais, 2007, p. 79-80;

36 Sem esquecer obviamente que eventual reapreciação do fundamento legal deverá se dar sob as diretrizes de um processo colaborativo, a fim de que decisões surpresas, decorrentes de um novo enquadramento atribuído pelo julgador aos fatos narrados no processo, sejam evitadas. MITIDIERO, Daniel. Colaboração no processo civil: pressupostos sociais, lógicos e éticos. 3. ed. rev. atual. e ampl. de acordo com o novo código de processo civil. São Paulo: Editora Revista dos Tribunais, 2015.

37 MELENDO, Santiago Sentis. El juez y el derecho: iura novit curia. Buenos Aires: Ediciones Juridicas Europa-America, 1957.
} 
publicista e em que o papel atribuído aos litigantes arrefeceu ${ }^{38}$ ) que se verificou a edição da primeira regra similar a essa máxima:

Tal regra permitia expressamente o juiz do processo da extraordinaria cognitio, do alto da posição assimétrica que ocupava, a suprir as carências argumentativas das partes e pronunciar sentença segundo the parecesse mais adequado sob a ótica da ordem jurídica do império ${ }^{39}$.

Em referido período, marcado por uma concentração de poderes, o Magistrado estava autorizado a suprir as eventuais omissões das partes, de modo que não era necessária a indicação de um nomen iuris à ação proposta ${ }^{40}$. Porém, a máxima iura novit curia, tal como chegou aos dias de hoje, remonta a período posterior: a passagem do ius commune para o direito moderno, na Europa, entre os séculos XVI e XVII ${ }^{41}$. O brocardo teve seu surgimento na Idade Média, pois “na França, já no século XIII se afirmava que a lei e o costume deveriam ser conhecidos pelo juiz" ${ }^{42}$. A formação da máxima com sua conotação atual, portanto, se deu a partir da composição entre a regra de origem romana e o brocardo em seu sentido medieval ${ }^{43}$.

Em sua tradicional concepção, “não só impõe ao juiz conhecer o direito e investiga-lo de ofício, caso não o conheça, mas torna também o órgão judicial totalmente independente na sua aplicação, desvinculando-o dos pedidos e alegações das partes a respeito" ${ }^{44}$. Nesse sentido é a lição de Fritz Baur, de acordo com o qual a subsunção dos fatos invocados pelas partes às normas jurídicas não consistiria em tarefa atribuível aos demandantes - indo tal entendimento ao encontro da máxima narra mihi factum, narro tibi ius ${ }^{45}$. Tem-se, nesse contexto, a tese de

\footnotetext{
${ }^{38}$ DOMIT, Otávio Augusto Dal Molin. lura novit curia e causa de pedir: o juiz e a qualificação jurídica dos fatos no processo civil brasileiro. In: MARINONI, Luiz Guilherme; ARENHART, Sérgio Cruz; MITIDIERO, Daniel (coord.). Coleção o novo processo civil. São Paulo: Editora Revista dos Tribunais, 2016, p. 50-58.

39 DOMIT, Otávio Augusto Dal Molin. Iura novit curia e causa de pedir: o juiz e a qualificação jurídica dos fatos no processo civil brasileiro. In: MARINONI, Luiz Guilherme; ARENHART, Sérgio Cruz; MITIDIERO, Daniel (coord.). Coleção o novo processo civil. São Paulo: Editora Revista dos Tribunais, 2016, p. 55.

${ }^{40} \mathrm{TUCCl}$, José Rogério Cruz e; AZEVEDO, Luiz Carlos de. Lições de história do processo civil romano. São Paulo: Editora Revista dos Tribunais, 1996, p. 145.

${ }^{41}$ DOMIT, Otávio Augusto Dal Molin. lura novit curia e causa de pedir: o juiz e a qualificação jurídica dos fatos no processo civil brasileiro. Coleção o novo processo civil. Coordenadores: Luiz Guilherme Marinoni, Sérgio Cruz Arenhart, Daniel Mitidiero. São Paulo: Editora Revista dos Tribunais, 2016, p. 68-69.

42 MELENDO, Santiago Sentis. El juez y el derecho: iura novit curia. Tradução livre. Buenos Aires: Ediciones Juridicas Europa-America, 1957, p. 15-16.

${ }^{43}$ DOMIT, Otávio Augusto Dal Molin. Iura novit curia e causa de pedir: o juiz e a qualificação jurídica dos fatos no processo civil brasileiro. In: MARINONI, Luiz Guilherme; ARENHART, Sérgio Cruz; MITIDIERO, Daniel (coord.). Coleção o novo processo civil. São Paulo: Editora Revista dos Tribunais, 2016, p. 68-69.

44 OLIVEIRA, Carlos Alberto Alvaro de. Do formalismo no processo civil: proposta de um formalismovalorativo. 4. ed. rev. atual. e aum. São Paulo: Saraiva, 2010, p. 222.

45 BAUR, Fritz. Da importância da dicção “iura novit curia”. Revista de Processo, n. 03, jul./set., 1976, p. 169/177, Trad. José Manoel Arruda Alvim, p. 169.
} 
que "a opinião concordante das partes a respeito de um elemento isolado de uma pretensão não vincula o juiz" 46 .

Séculos passaram desde então e atualmente o sistema processual civil brasileiro traz exceções à aplicabilidade dessa faceta antiga do adágio iura novit cúria. Dentre as hipóteses de limitação encontra-se a previsão do art. 357, \$2 , do Código de Processo Civil/2015, segundo a qual "as partes podem apresentar ao juiz, para homologação, delimitação consensual das questões de fato e de direito a que se referem os incisos II e IV, a qual, se homologada, vincula as partes e o juiz".

A delimitação consensual dessas questões, prevista nesse dispositivo atingirá, portanto, as questões fáticas sobre as quais recairá a atividade probatória (art. 357, II, do CPC/2015) e as questões de direito relevantes para a decisão do mérito (art. 357, IV, do CPC/2015). Tem-se, portanto, um negócio jurídico vinculativo às partes e ao juiz, na esteira de uma promoção da autonomia da vontade também na seara processual.

Vale ter consciente que o objeto litigioso já estava desde a petição inicial limitado pela eleição da causa de pedir pelo autor - na qual a fundamentação jurídica é parte constitutiva -, sendo indisponível à atuação do juiz, por consideração do princípio dispositivo em sentido material. No entanto, a questão mostra-se juridicamente delicada quando, na doutrina e nos tribunais, são defendidas projeções do brocardo iura novit curia a ponto de destituir a vinculatividade da vontade na definição do objeto litigioso, com a reconfiguração da causa de pedir pelo juiz, o que se dá com a modificação dos fundamentos jurídicos de ofício.

A propósito, não é incomum a defesa de que “o juiz não estaria vinculado à fundamentação jurídica da demanda, estando livre para desconsiderá-la, modificá-la em alguns de seus termos ou alterá-la completamente" ${ }^{47}$. Nesse sentido, a lição de Cândido Rangel Dinamarco:

No tocante à causa petendi, o art. 264 impede que o autor imponha ao réu qualquer alteração dos fatos descritos na petição inicial à guisa de fundamento do pedido. Embora também os fundamentos jurídicos se reputem incluídos na causa de pedir e os exija a lei como requisito da petição inicial (art. 282, inc. III),

\footnotetext{
${ }^{46}$ BAUR, Fritz. Da importância da dicção "iura novit curia”. Revista de Processo, n. 03, jul./set., 1976, p. 169/177, Trad. José Manoel Arruda Alvim, p. 169.

${ }^{47}$ Nesse sentido, ver crítica tecida a essa abordagem em DOMIT, Otávio Augusto Dal Molin. lura novit curia e causa de pedir: o juiz e a qualificação jurídica dos fatos no processo civil brasileiro. Coleção o novo processo civil. Coordenadores: Luiz Guilherme Marinoni, Sérgio Cruz Arenhart, Daniel Mitidiero. São Paulo: Editora Revista dos Tribunais, 2016 In: MARINONI, Luiz Guilherme; ARENHART, Sérgio Cruz; MITIDIERO, Daniel (coord.). Coleção o novo processo civil. São Paulo: Editora Revista dos Tribunais, p. 286.
} 
eles não concorrem para a determinação dos limites do julgamento de mérito a ser feito afinal. 0 que deve permanecer íntegro é a narrativa de fatos, porque fora destes o juiz jamais poderá julgar (art. 128) e é dos fatos narrados que o réu se defenderá (regime da substanciação - infra, n. 450). Da causa de pedir, somente a narrativa do fato se estabiliza, até porque, quanto aos fundamentos jurídicos, o próprio juiz pode trazer outros diferentes dos que o autor haja alegado (narra mihi factum dabo tibi ius) ${ }^{48}$.

Esse pressuposto, no entanto, acaba por negar vigência parcial ao princípio dispositivo em sentido material e permite seja reeditado elemento da ação processual conforme a vontade do juiz. Afinal, em última análise, enseja a viabilidade de um reenquadramento jurídico da demanda pelo magistrado, com alteração da causa de pedir e, consequentemente, do objeto litigioso do processo ${ }^{49}$.

Nessa esteira, cabe questionar qual o papel do negócio jurídico previsto no art. 357, $\S 2^{\circ}$, do CPC/2015. Afinal, ter-se-ia mera uma redundância legal se tal importasse simplesmente a sinalização ao Magistrado que a definição do enquadramento jurídico da causa de pedir cabe às partes, haja vista a incidência do princípio dispositivo em sentido material. Dita explicitação dos limites do objeto litigioso poderiam ser promovidas por petições unilaterais das partes ou por meras recomendações de leitura, especialmente quando tais posturas decorrem de elementos fundadores da teoria geral do processo.

Afinal, a questão estaria delimita desde cedo, com a identificação da causa petendi na vestibular. Igualmente, indaga-se se o negócio jurídico em questão alcançaria o objeto clássico de incidência do adágio iura novit curia, ou seja, os fundamentos legais, hipótese que será abordada na sequência.

\footnotetext{
48 DINAMARCO, Cândido Rangel. Instituições de Direito Processual Civil. Vol. II. 6. ed. rev. e atual. São Paulo: Malheiros Editores, 2009, p. 74.

49 Otávio Augusto Dal Molin Domit, a respeito, consigna que "Esse poder [do juiz de alterar a fundamentação jurídica da demanda] seria decorrência do suposto dever de o juiz estimar a controvérsia e a respectiva questão jurídica envolvida de maneira livre, do modo como entender mais adequado e correto à luz dos fatos expostos, aplicando o direito à espécie com vistas à prolação de decisão que companha da melhor forma possível o litígio. A máxima iura novit curia, assim dotaria o juiz de poderes para interferir na qualificação jurídica do fato ou conjunto de fatos narrados tal como proposta pelo demandante, bem assim na derivação das consequências jurídicas atribuídas pelo autor a esses fatos juridicamente identificados, a fim de engendrar a solução jurídica que the parecer mais propícia e acertada para o caso, observada unicamente a limitação imposta pelo pedido. É com esse conteúdo normativo, portanto, que a máxima diretamente se vincula à temática relativa ao formalismo processual". Vide DOMIT, Otávio Augusto Dal Molin. lura novit curia e causa de pedir: o juiz e a qualificação jurídica dos fatos no processo civil brasileiro In: MARINONI, Luiz Guilherme; ARENHART, Sérgio Cruz; MITIDIERO, Daniel (coord.). Coleção o novo processo civil. São Paulo: Editora Revista dos Tribunais, 2016, p. 286.
} 


\section{AS CONVENÇÕES PROCESSUAIS E AS LIMITAÇÕES AOS PODERES DO JUIZ}

\subsection{Processo e privatismo}

O procedimento previsto pela legislação processual brasileira foi historicamente considerado como composto por regras majoritariamente cogentes. Isso significa que as regras procedimentais não poderiam ser alteradas pelos litigantes nem pelo Magistrado ainda que a todos conviessem mudanças ${ }^{50}$. Nessa seara, O CPC/1973 limitou de maneira contundente a autonomia privada dos litigantes, pois suprimiu quase que integralmente as projeções que o princípio dispositivo em sentido formal poderia transpassar ao procedimento.

Contudo, como bem pontuado por Fredie Didier Jr., “o Direito Processual Civil, embora ramo do Direito Público, ou talvez exatamente por isso, também é regido pela dimensão da liberdade" ${ }^{21}$, sendo relevante destacar que, embora no âmbito processual as regras tenham sido tradicionalmente concebidas como cogentes, no âmbito do direito material as partes sempre gozaram de liberdade para transacionar o fim da controvérsia, mesmo que a questão já estivesse judicializada ${ }^{52}$. Seguindo tal linha, e recrudescendo os poderes dos demandantes na celebração de convenções processuais, o CPC/2015 sugere a autocomposição como medida de solução de conflitos em diversos dispositivos ${ }^{53}$, inclusive recaindo sobre objetos antes vetados, rompendo, portanto, com premissas que estavam há muito cristalizadas em nosso ordenamento jurídico.

O novo diploma processual civil prevê um número significativo de negócios processuais típicos, para além da cláusula geral de atipicidade constante no art. 190, do Código de Processo Civil/2015 $5^{54}$. Tem-se, assim, que as convenções processuais passaram a ostentar "natureza e

\footnotetext{
50 TUCCl, José Rogério Cruz e. Natureza e objeto das convenções processuais. In: CABRAL, Antonio do Passo; NOGUEIRA, Pedro Henrique (coord.). Negócios Processuais. 2. ed. rev. atual. e ampl. Salvador: Editora JusPodivm, 2016, p. 23-29, p. 23.

${ }^{51}$ DIDIER JR., Fredie. Princípio do respeito ao autorregramento da vontade no processo civil. In: CABRAL, Antonio do Passo; NOGUEIRA, Pedro Henrique (coord.). Negócios Processuais. 2. ed. rev. atual. e ampl. Salvador: Editora JusPodivm, 2016, p. 31-37, p. 32.

52 TUCCl, José Rogério Cruz e. Natureza e objeto das convenções processuais. In: CABRAL, Antonio do Passo; NOGUEIRA, Pedro Henrique (coord.). Negócios Processuais. 2. ed. rev. atual. e ampl. Salvador: Editora JusPodivm, 2016, p. 23-29, p. 23-24.

53 TUCCl, José Rogério Cruz e. Natureza e objeto das convenções processuais. In: CABRAL, Antonio do Passo; NOGUEIRA, Pedro Henrique (coord.). Negócios Processuais. 2. ed. rev. atual. e ampl. Salvador: Editora JusPodivm, 2016, p. 23-29, p. 24.

54 Art. 190, Código de Processo Civil/2015. Versando o processo sobre direitos que admitam autocomposição, é lícito às partes plenamente capazes estipular mudanças no procedimento para ajustá-
} 
conteúdo estritamente processual" ${ }^{55}$, aumentando a liberdade de conformação do procedimento pelas próprias partes litigantes.

Faz-se possível traçar uma distinção entre os negócios jurídicos processuais que influenciam a situação jurídica titularizada pelo julgador e aqueles que não a influenciam. Assim sendo, nas hipóteses em que o juiz não é sujeito do negócio jurídico processual, sua atuação limitar-se-á à mera verificação da validade do negócio processual realizado pelas partes ${ }^{56}$ ou, quando for o caso, à sua homologação (situação em que deverá analisar se o negócio jurídico processual encontra-se em conformidade com o ordenamento jurídico ${ }^{57}$. Por outro lado, diferentes são as hipóteses em que a atuação do juiz é necessária para que o ato preencha seus requisitos de validade. Nesses casos, tem-se verdadeiros "negócios processuais plurilaterais, ou seja, que exigem a manifestação de vontade válida das partes e do magistrado"58; o juiz passa a atuar como um sujeito do ato que está sendo praticado, sendo que um exemplo de tal situação é justamente o previsto no art. $357, \$ 2^{\circ}$, do novo Código de Processo Civil: o saneamento consensual do processo.

lo às especificidades da causa e convencionar sobre os seus ônus, poderes, faculdades e deveres processuais, antes ou durante o processo.

Parágrafo único. De ofício ou a requerimento, o juiz controlará a validade das convenções previstas neste artigo, recusando-lhes aplicação somente nos casos de nulidade ou de inserção abusiva em contrato de adesão ou em que alguma parte se encontre em manifesta situação de vulnerabilidade.

55 TUCCI, José Rogério Cruz e. Natureza e objeto das convenções processuais. In: CABRAL, Antonio do Passo; NOGUEIRA, Pedro Henrique (coord.). Negócios Processuais. 2. ed. rev. atual. e ampl. Salvador: Editora JusPodivm, 2016, p. 23-29, p. 28.

${ }^{56}$ Sobre os requisitos de existência, validade e eficácia dos negócios jurídicos processuais: "São 05 (cinco) os pressupostos de existência dos negócios processuais: (i) agente (capacidade de ser parte); (ii) vontade; (iii) autorregramento da vontade; (iv) objeto; e (v) forma. Por seu turno, são 07 (sete) os requisitos de validade dos negócios: (i) capacidade processual (e postulatória, quando o negócio for judicial); (ii) liberdade (da vontade); (iii) equilíbrio (inexistência de vulnerabilidade ou hipossuficiência); (iv) precisão, determinabilidade, previsibilidade, possibilidade e licitude do objeto; (v) direito substancial (res in iudicium dedecta) passível de autocomposição; (vi) adequação (da forma); e (vii) proporcionalidade/razoabilidade do conteúdo convencionado (ato, instituto ou medida)". REDONDO, Bruno Garcia. Negócios jurídicos processuais: existência, validade e eficácia. Panorama atual do novo CPC. Pedro Miranda de Oliveira... [et al]; Coordenador: Paulo Henrique dos Santos Lucon e Pedro Miranda de Oliveira. Florianópolis: Empório do Direito, 2016. p. 27-3, p. 28-29.

${ }^{57}$ AVELINO, Murilo Teixeira. A posição do magistrado em face dos negócios jurídicos processuais - já uma releitura. In: CABRAL, Antonio do Passo; NOGUEIRA, Pedro Henrique (coord.). Negócios Processuais. 2. ed. rev. atual. e ampl. Salvador: Editora JusPodivm, 2016, p. 367-390, p. 378.

${ }^{58}$ AVELINO, Murilo Teixeira. A posição do magistrado em face dos negócios jurídicos processuais - já uma releitura. In: CABRAL, Antonio do Passo; NOGUEIRA, Pedro Henrique (coord.). Negócios Processuais. 2. ed. rev. atual. e ampl. Salvador: Editora JusPodivm, 2016, p. 367-390, p. 382. 


\subsection{Art. 357, $\$ 2^{\circ}$, do CPC/2015: a delimitação do objeto litigioso via convenção processual}

Dispõe o parágrafo segundo do art. 357 que "as partes podem apresentar ao juiz, para homologação, delimitação consensual das questões de fato e de direito a que se referem os incisos II e IV, a qual, se homologada, vincula as partes e o juiz". Tal previsão consiste na regulação de um negócio processual típico por intermédio do qual as partes têm a oportunidade de delimitar as questões de direito e de fato objeto do processo.

Impõe-se ter em mente que as questões de fato e de direito diretamente vinculadas ao julgamento do mérito são decorrentes de manifestações de vontade das partes. Se é exclusividade do autor apresentar a pretensão material na inicial, algumas defesas são igualmente dependentes da vontade da parte ré para serem avaliadas em juízo, como ocorre com as exceções materiais. O princípio dispositivo em sentido material, portanto, incide também para a defesa, de modo que não pode o juiz, v.g., suscitar a exceção do contrato não cumprido (art. 476, do CCB/2002), sem que tenha o réu a deduzido tempestivamente.

Nesse sentido, um dos objetivos do negócio processual previsto no art. 357, $\$ 2^{\circ}$, do CPC/2015 é explicitar as questões sujeitas a decisão, significando parâmetro para as partes e para o juiz. Trata-se, outrossim, da última oportunidade disponível para eventual alteração dos objetos das discussões meritórias, por conta da estabilização que se opera após o saneamento, nos termos do art. 329, II, do CPC/2015.

A convenção processual em questão também determina a produção probatória subsequente. A delimitação das questões de fato orienta a conduta das partes "quanto aos fatos alegados de ocorrência ou de modo de ser duvidosos, sobre os quais deverão se empenhar para demonstrá-los, e, ao mesmo tempo, determinar quais são as alegações de fatos já demonstradas e sobre as quais a atividade probatória é inútil"59.

A questões de direito designadas no negócio saneador - além de afixar elementos de previsibilidade na decisão e direcionar a uma decisão não fundada em surpresa - também servem como elementos de organização da própria instrução. Isso porque embora elas não integrem o objeto da prova (exceção apenas no que tange à necessidade de prova do teor e vigência do direito municipal, estadual, estrangeiro e consuetudinário, conforme art. 376, do (PC/2015), a

59 YARSHELL, Flávio Luiz; PEREIRA, Guilherme Setoguti J; RODRIGUES, Viviane Siqueira. Comentários ao Código de Processo Civil: artigos 334 ao 368. In: MARINONI, Luiz Guilherme; ARENHART, Sérgio Cruz; MITIDIERO, Daniel. Coleção Comentários ao Código de Processo Civil. v.5. São Paulo: Editora Revista dos Tribunais, 2016, p. 283. 
sua delimitação interfere no interesse de provar e, consequentemente, na fase instrutória ${ }^{60}$. Afinal, em exemplo singelo, se for incontroversa a designação da qualificação jurídica como de responsabilidade civil objetiva - uma indiscutível questão jurídica -, dificilmente ter-se-á qualquer interesse em produzir prova acerca da ocorrência da culpa de um dos contendores.

Nessa toada, verifica-se, assim, que o negócio jurídico processual em questão, com a possibilidade de delimitação das questões de fato e de direito, tem como primeira função explicitar o objeto litigioso do processo, influenciando na subsequente produção de provas, com a delimitação de seus exatos limites ${ }^{61}$. Orienta, outrossim, a fundação da decisão meritória em um ambiente que assegura o pleno contraditório e traça uma rota no procedimento que afasta a prolação de decisões surpresa.

Questiona-se sobre a natureza do ato do Magistrado diante de uma convenção processual que saneie consensualmente o feito: a atuação do juiz seria de fato uma homologação do acordo já realizado pelos litigantes (sendo, desta maneira, uma mera condição para que o ato possa produzir seus efeitos) ou se trata de uma situação na qual a vontade do julgador é relevante? ${ }^{62}$

Acerca de tal discussão, Murilo Teixeira Avelino sustenta que o magistrado deve concordar com o saneamento consensual, pois "há a disposição a respeito das questões de fato que serão objeto de prova e de direito relevantes para a decisão, elementos que obviamente influenciam na atuação do juiz no processo". Complementa indicando que o juiz "titulariza uma situação que tem como elemento necessário toda a matéria de fato e de direito necessárias ao seu convencimento e tomada de decisão. As partes não podem a respeito disso dispor sem que o juiz participe ativamente do negócio processual"63.

Não é esta, contudo, a nossa interpretação. Afinal, as partes podem alterar o objeto litigioso por acordo até o saneamento. 0 negócio em exame se trata efetivamente de um modo

60 YARSHELL, Flávio Luiz; PEREIRA, Guilherme Setoguti J; RODRIGUES, Viviane Siqueira. Comentários ao Código de Processo Civil: artigos 334 ao 368. In: MARINONI, Luiz Guilherme; ARENHART, Sérgio Cruz; MITIDIERO, Daniel. Coleção Comentários ao Código de Processo Civil. v.5. São Paulo: Editora Revista dos Tribunais, 2016, p. 286.

61 YARSHELL, Flávio Luiz; PEREIRA, Guilherme Setoguti J; RODRIGUES, Viviane Siqueira. Comentários ao Código de Processo Civil: artigos 334 ao 368. In: MARINONI, Luiz Guilherme; ARENHART, Sérgio Cruz; MITIDIERO, Daniel. Coleção Comentários ao Código de Processo Civil. v.5. São Paulo: Editora Revista dos Tribunais, 2016, p. 286.

${ }^{62}$ AVELINO, Murilo Teixeira. A posição do magistrado em face dos negócios jurídicos processuais - já uma releitura. In: CABRAL, Antonio do Passo; NOGUEIRA, Pedro Henrique (coord.). Negócios Processuais. 2. ed. rev. atual. e ampl. Salvador: Editora JusPodivm, 2016, p. 367-390, p. 385.

${ }^{63}$ AVELINO, Murilo Teixeira. A posição do magistrado em face dos negócios jurídicos processuais - já uma releitura In: CABRAL, Antonio do Passo; NOGUEIRA, Pedro Henrique (coord.). Negócios Processuais. 2. ed. rev. atual. e ampl. Salvador: Editora JusPodivm, 2016, p. 367-390, p. 385-386. 
ISSN 1981-3694

(DOI): $10.5902 / 1981369429673$

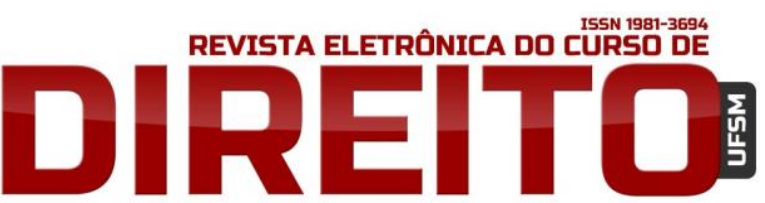

O NEGÓCIO PROCESSUAL SANEADOR: ENTRE O PRINCÍPIO DISPOSITIVO MATERIAL E O IURA NOVIT CURIA

EDUARDO KOCHENBORGER SCARPARO CAROLINE POMJÉ

típico de realização dessa diretiva. Para essa conclusão, deve-se considerar que tanto a primeira delimitação quanto as alterações sobre o objeto litigioso não são disponíveis ao magistrado. Ao juiz cabe tão somente acatar o acordo, a partir do reconhecimento de que o objeto litigioso tem instauração e limitações condicionadas pela vontade privada das partes, desde a distribuição da inicial pelo autor e pela oferta ou não de exceções materiais pelo réu. Isso por força da incidência do princípio dispositivo em sentido material.

A dicção iura novit curia, portanto, por força da natureza do negócio jurídico em questão, perde espaço para o princípio dispositivo em sentido material, cuja incidência é reforçada pela convenção que pode vir a ser realizada pelos litigantes em sede de saneamento. 0 adágio iura novit curia teria incidência apenas nas hipóteses em que não incide o princípio dispositivo em sentido material, tal qual ocorre nos casos de objeções materiais como a decadência e a prescrição, bem como naquelas matérias em que se reconhece a possibilidade de atuação de ofício do juiz.

Desta forma, a decisão que homologa o saneamento consensual sobre o objeto litigioso é dotada de eficácia apenas declaratória, pois está lastreada na reafirmando de incidência do princípio dispositivo em sentido material. O negócio em si pode significar alterações no objeto litigioso, a partir de manifestações de vontade das partes, mas a homologação pelo juiz não cria situações jurídicas novas, apenas as reconhece.

Retome-se que a delimitação da fundamentação jurídica aplicável ao caso concreto fica a critério das partes, pois condiz com elemento constitutivo e identificador da causa de pedir e, consequentemente, da ação exercida. Assim porque defende-se a não incidência do adágio iura novit curia no que tange à fundamentação jurídica da causa de pedir, conforme já justificado anteriormente. É igualmente oportuno destacar que o negócio jurídico em questão não exerce influência sobre a fundamentação legal - indicação dos dispositivos legais pertinentes à análise do caso -, de modo que o magistrado não se encontrará de nenhuma forma vinculado aos dispositivos de lei porventura indicados pelas partes no saneamento do processo. A ausência de vinculação do magistrado ao negócio jurídico em questão decorre do fato de que a fundamentação legal da demanda não compõe a causa de pedir, de modo que doutrinária e jurisprudencialmente fixou-se o entendimento - já secular - no sentido de que, por força do brocardo iura novit curia, o juiz poderia requalificar legalmente a demanda.

Consequentemente, tem-se que o negócio jurídico de saneamento do processo, previsto no art. 357, $\$ 2^{\circ}$, do CPC/2015, visa a explicitar o objeto litigioso do processo às partes e ao magistrado, influenciando na atividade probatória e decisória subsequente, de modo que as 
provas carreadas aos autos serão pré-ordenadas em decorrência do saneamento do processo e o juiz restará vinculado aos fundamentos jurídicos invocados pelas partes e estabilizados no saneamento. Pode igualmente servir para redesenhar em consenso entre o autor e o réu as questões de mérito sobre as quais deve recair a decisão judicial, cenário em que pode haver a inclusão, a modificação ou a exclusão de aspectos determinantes da identificação da ação exercida ou das exceções materiais promovidas pelas partes. Ao juiz resta a régua do princípio dispositivo material, ao qual sempre esteve vinculado.

\section{CONCLUSÃO}

A homologação do negócio jurídico por meio do qual se procede ao saneamento consensual do processo ressalta a vinculação da atividade subsequente dos litigantes e do juiz. 0 magistrado não poderá invocar fundamento jurídico diverso daqueles constantes da decisão de saneamento estabilizada quando da prolação da decisão meritória. O saneamento vincula e direciona a atividade das partes e a atividade jurisdicional.

Ao prolatar a decisão final, o julgador encontrar-se-á vinculado àqueles fundamentos jurídicos constantes da decisão de saneamento estabilizada, de modo que não poderá proceder à invocação de algum fundamento diverso daqueles sobre os quais as partes já tiveram oportunidade de se manifestar - e que, inclusive, foram objeto de negócio jurídico processual vinculante.

Contemporaneamente, portanto, o adágio iura novit curia deve ter sua margem de aplicabilidade visivelmente reduzida, de modo que o direito aplicável ao caso concreto deverá respeitar aqueles limites previamente estabelecidos pelas partes litigantes, por força da incidência do princípio dispositivo em sentido material tanto pelas limitações incidentes pela ação exercida pelo autor, como pelas exceções materiais apresentadas pelo réu. 0 negócio processual em questão reafirma esses limites.

\section{REFERÊNCIAS}

ALVARO DE OLIVEIRA, Carlos Alberto. Do formalismo no processo civil. 4. ed. São Paulo: Saraiva, 2010,

ARENHART, Sergio Cruz. Reflexões sobre o princípio da demanda. In: FUX, Luiz; NERY JR., Nelson; WAMBIER, Teresa Arruda Alvim (coord.). Processo e Constituição: estudos em 
homenagem ao Professor José Carlos Barbosa Moreira. São Paulo: Editora Revista dos Tribunais, 2006.

AVELINO, Murilo Teixeira. A posição do magistrado em face dos negócios jurídicos processuais já uma releitura. In: CABRAL, Antonio do Passo; NOGUEIRA, Pedro Henrique (coord.). Negócios Processuais. 2. ed. rev. atual. e ampl. Salvador: Editora JusPodivm, 2016.

BAUR, Fritz. Da importância da dicção “iura novit curia”. Revista de Processo, n. 03, jul./set., 1976, p. 169/177, Trad. José Manoel Arruda Alvim.

BÜLOW, Oskar. La teoría de las excepciones procesales y los presupuestos procesales. Tradução de Miguel Angel Rosas Lichtschein. Buenos Aires: EJEA, 1964.

CABRAL, Antonio do Passo. Convenções processuais. Salvador: Editora JusPodivm, 2016.

CAPPELLETTI, Mauro. La testimonianza della parte nel sistema dell'oralità. v. 1. Milão: Giuffrè, 1962.

CARNACINI, Tito. Tutela giurisdizionale e tecnica del processo. In: Studi in onore di Enrico Redenti. v. 2. Milão: Giuffrè, 1951.

DIDIER JR., Fredie. Princípio do respeito ao autorregramento da vontade no processo civil. In: CABRAL, Antonio do Passo; NOGUEIRA, Pedro Henrique (coord.). Negócios Processuais. 2. ed. rev. atual. e ampl. Salvador: Editora JusPodivm, 2016.

DINAMARCO, Cândido Rangel. Instituições de Direito Processual Civil. Vol. II. 6. ed. rev. e atual. São Paulo: Malheiros Editores, 2009.

DOMIT, Otávio Augusto Dal Molin. Iura novit curia e causa de pedir: o juiz e a qualificação jurídica dos fatos no processo civil brasileiro. In: MARINONI, Luiz Guilherme; ARENHART, Sérgio Cruz; MITIDIERO, Daniel (coord.). Coleção o novo processo civil. São Paulo: Editora Revista dos Tribunais, 2016.

HOFFMANN JÚNIOR, Lírio. A teoria da substanciação e seus reflexos sobre a coisa julgada. In: OLIVEIRA, Pedro Miranda de; LUCON, Paulo Henrique dos Santos (coord.). Panorama atual do novo CPC. Florianópolis: Empório do Direito, 2016.

MELENDO, Santiago Sentis. El juez y el derecho: iura novit curia. Buenos Aires: Ediciones Juridicas Europa-America, 1957.

MESQUITA, José Ignácio Botelho de. A coisa julgada. Rio de Janeiro: Forense, 2006.

MOREIRA, José Carlos Barbosa. O problema da “divisão do trabalho" entre juiz e partes: aspectos terminológicos. Revista de Processo, São Paulo, n. 41, p. 7-14, jan/mar.1986.

OLIVEIRA, Carlos Alberto Alvaro de. Do formalismo no processo civil: proposta de um formalismo-valorativo. 4. ed. rev. atual. e aumentada. São Paulo: Saraiva, 2010.

PINTO, Junior Alexandre Moreira. A causa petendi e o contraditório. São Paulo: Editora Revista dos Tribunais, 2007. 
SANCHES, Sydney. Objeto do processo e objeto litigioso do processo. Revista da AJURIS. Ano VI 1979, julho. p. 133-156.

TUCCI, José Rogério Cruz e. A denominada "situação substancial" como objeto do processo na obra de Fazzalari. Revista de Processo, v. 68/1992, p. 271-281, out-dez, 1992.

TUCCI, José Rogério Cruz e. Natureza e objeto das convenções processuais. In: CABRAL, Antonio do Passo; NOGUEIRA, Pedro Henrique (coord.). Negócios Processuais. 2. ed. rev. atual. e ampl. Salvador: Editora JusPodivm, 2016.

TUCCI, José Rogério Cruz e; AZEVEDO, Luiz Carlos de. Lições de história do processo civil romano. São Paulo: Editora Revista dos Tribunais, 1996.

YARSHELL, Flávio Luiz; PEREIRA, Guilherme Setoguti J; RODRIGUES, Viviane Siqueira. Comentários ao Código de Processo Civil: artigos 334 ao 368. In: MARINONI, Luiz Guilherme; ARENHART, Sérgio Cruz; MITIDIERO, Daniel. Coleção Comentários ao Código de Processo Civil. v.5. São Paulo: Editora Revista dos Tribunais, 2016.

\section{COMO FAZER A REFERÊNCIA DO ARTIGO (ABNT):}

SCARPARO, Eduardo Kochenborger; POMJÉ, Caroline. O negócio processual saneador: entre o princípio dispositivo material e o iura novit curia. Revista Eletrônica do Curso de Direito da UFSM, Santa Maria, RS, v. 13, n. 3, p. 9951015, dez. 2018. ISSN 1981-3694. Disponível em: < https://periodicos.ufsm.br/revistadireito/article/view/29673 >. Acesso em: dia mês. ano. doi: http://dx.doi.org/10.5902/1981369429673 . 